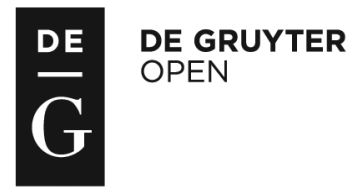

Administration, vol. 63, no. 2 (2015), pp. 149-176

doi: 10.1515/admin-2015-0014

\title{
City regions and the changing role of local government in supporting their economic growth potential
}

\author{
Jamie Cudden \\ Dublin City Council
}

\section{Introduction}

This paper sets out global trends in urban development, with a particular emphasis on the role of Dublin and its evolution as an important hub in the global economy (Foley et al., 2012). It highlights areas such as regional governance, spatial planning and the changing role of local economic development. The paper also documents a number of economic development initiatives that were implemented in Dublin following the economic downturn in 2007. Local government has had to adapt as a result of the economic crises and there is now a much stronger focus on supporting local economic development, with a new emphasis on action planning with robust monitoring and impact measurements. With the economic recovery in motion there is a need to consider the best policies to ensure that Ireland's city regions, and in particular Dublin, as Ireland's economic engine, can compete successfully on a global stage.

The twenty-first century is one which is increasingly dominated by city regions that are growing in influence both economically and politically (Dublin Chamber of Commerce, 2012). Cities are competing strongly for mobile investment, talent and tourism, with investment decisions being made between cities and not countries 
(Economist Intelligence Unit, 2012). City mayors increasingly dominate national politics and exert a growing influence on the national and international stage (C40, 2015). There is extensive literature setting out the advantages of an urban setting with associated concentrations of knowledge and innovation, which leads to increased productivity and economic performance (Glaeser, 2011; Krugman, 1991; OECD, 2006; Porter, 1990; Sassen, 2011). Successful cities are ones that are able to differentiate themselves through their infrastructure offering and liveability (National Competitiveness Council, 2009).

Dublin has transformed itself as a leading international gateway that is highly embedded in the global economy (Taylor, 2010) and dominates its national economy (Central Statistics Office, 2015). Dublin's surrounding counties, and Ireland as a whole, benefit significantly from these positive spillover effects (Forfás, 2009; Williams et al., 2012a). However, there are also many challenges faced by growing city regions, including urban sprawl, congestion, increased commute distance and unsustainable development patterns (Williams et al., 2012b). City regions in many countries dominate their national economies, which also leads to challenges in accomplishing balanced regional development and in turn creates urban-rural political tensions (Curren, 2015; D'arcy, 2015; Weston, 2015).

A series of failed spatial planning policies from the 1960s has resulted in a situation where Dublin now dominates nationally (Hughes, 2010). There is currently an absence of a national spatial strategy and a regional governance model, which has led to some uncertainty. The next iteration of the National Spatial Strategy (NSS; Government of Ireland, 2002) needs to focus on what is best for the future economic growth of this country, as opposed to what is politically acceptable. Ireland's city regions, and in particular Dublin, require the right policy framework to compete successfully on a global stage.

Local government in Ireland plays an important role in driving local economic urban development. However, its impact is limited through the absence of a suite of appropriate powers and responsibilities that are available to the majority of OECD cities (OECD, 2014a). This in turn makes for a challenging operating environment. In spite of this, local government has developed a wide range of supports and interventions to support local economic development (County and City Managers' Association, 2013). There have been a number of approaches to support Dublin regional economic growth, including projects such as the Creative Dublin Alliance (CDA), the delivery of a 
Dublin region economic plan and a unique collaboration between the business community and government called Activating Dublin.

The move towards an enhanced role for local government in local economic development, as envisaged through Putting People First (Department of the Environment, Community and Local Government, 2012) and enacted by The Local Government Reform Act, 2014, will better align national, regional and local delivery of economic and community development (Department of the Environment, Community and Local Government, 2015). The vision of this reform was for local government to be the engine behind recovery. This should reap rewards, assuming that the agreed actions are practical, evidencebased, and monitored and evaluated accordingly. The launch of Dublin's first Quarterly Economic Monitor in April 2015, a combined effort of the four Dublin local authorities, reflects this new role for local government (Dublin City Council, 2015a).

\section{Cities driving the global economy}

The future will be won or lost in the world's cities. Over 50 per cent of the global population live in urban areas, up from 30 per cent in 1950, accounting for over 80 per cent of global GDP (McKinsey Global Institute, 2011). The UN predicts that by 2050 over two-thirds of the world's population will be concentrated in urban areas, most of them in developing countries (UN Population Division, 2014). How the world responds to this rapid growth of urbanisation will define future generations' levels of prosperity.

It is not uncommon for cities to account for a significant share of their national GDP. In the US, for example, the majority of national GDP is generated from a network of metro economies. The top 100 US metropolitan areas comprise about 12 per cent of the country's land mass, have 65 per cent of the population and generate 75 per cent of the GDP (Colford, 2013). The Dublin City Region in 2012 (based on a harmonised functional definition developed by the OECD) had the third-highest concentration of city-to-country GDP in the OECD, accounting for 42 per cent of the national total (OECD, 2015). Only Tallinn and Seoul had higher concentrations of GDP to their national total in the OECD. In terms of comparable European cities, Copenhagen, Vienna, Athens and Budapest share similar traits to Dublin.

Dublin's role in Ireland's economy provides a somewhat extreme example of what is a worldwide phenomenon, namely the increasing 
concentration of the world's economic activity and population in city regions. According to the Economist Intelligence Unit, 'global business is beginning to plan strategy from a city, rather than a country, perspective' (2012).

The rising importance of cities is also reflected in the attention received by international organisations such as the OECD (2015), the UN Population Division (2014) and the World Bank (2015). Cities are also a hot topic amongst many of the world's leading professional and consultancy firms; for example, see IBM's Smarter Cities programme (2015), PwC's Cities of Opportunity (2015), KPMG's Global Cities Investment Monitor (2015), Knight Frank's Global Cities Index (2015), A. T. Kearney's Global Cities Index (2015) and MasterCard's Global Destination Cities Index (2015).

In 2011 McKinsey mapped the economic power of the top 600 cities, which demonstrated that they accounted for 60 per cent of global GDP (McKinsey Global Institute, 2011). It is expected that by the year 2025, 60 per cent of global GDP will still be generated by just 600 city regions. However, the make-up of these will change dramatically, with one in every three developed city regions likely to drop out of the top 600 and be replaced by city regions in developing countries.

There are also increasing numbers of research institutes focusing on cities, including the London School of Economics Cities Institute (see https://lsecities.net) and the Globalisation and World Cities programme (see www.lboro.ac.uk/gawc/). The Brookings Institute in the US has recently partnered with JP Morgan Chase Bank to drive a 'Global Cities Initiative' to support US metropolitan leaders to reorient their economies toward greater engagement in world markets (Brookings, 2015).

There is an increasing interest in the benchmarking of city regions, with Jones Lang La Salle reviewing over 150 of the leading international city benchmarks (Jones Lang La Salle, 2013). These include benchmarks ranging from quality of living, costs of living (Mercer, 2015), innovation capacity (2thinknow, 2014) and sustainability measures (Siemens, 2009). The Dublin City Region, while a small city region in the international context, features in many of these global indices and is projected to maintain its position as a leading global city by 2020 and 2025 (A. T. Kearney, 2015; Economist Intelligence Unit, 2012; McKinsey Global Institute, 2011). Furthermore, with increasing attention on cities, a new standard for the development of globally comparable city indicators, known as ISO 
37120 , will now allow cities ways to compare themselves with peer cities around the globe (ISO, 2014).

\section{The increasing influence of city mayors}

City regions increasingly dominate their national politics, with mayors from cities such as London and New York exerting increasing influence on a national and international stage. Initiatives such as the Carbon Disclosure Project (2010), which was driven by city mayors, and The New Climate Economy (2014) recognise the increasing economic importance of cities and the pivotal roles that they can play in tackling climate change, as they account for 70 per cent of the world's greenhouse gas emissions (UN, 2011). The C40 Cities Climate Leadership Group connects more than seventy-five of the world's largest cities (representing over 550 million people) and is focused on tackling climate change (C40, 2015)

Opinion on the role of mayors in building successful cities is divided, with strong arguments put forward on both sides (Beehner, 2014; Geoghegan, 2013; Lever, 2001). Benjamin R. Barber's 2013 book If Mayors Ruled the World: Dysfunctional Nations, Rising Cities asserts that cities and the mayors who run cities offer the best forces of good governance. They are better placed than the nation state to tackle complex problems of climate change, terrorism, poverty and drugs.

Cities play an important role in their national economies as well as the global economy (OECD, 2006). Furthermore, this trend of urbanisation is set to continue, with cities becoming even more important going forward (UN Population Division, 2014). While the Dublin City Region may appear dominant in a national context, at an international level Dublin is a small city on the margins of north-west Europe (Forfás, 2009). How small countries like Ireland respond to this trend will define future competitiveness and economic prosperity.

\section{Agglomeration economies and clustering}

Cities have long been recognised as centres of economic growth based on the increased potential to exploit economies of scale in various forms. For example, firms located in cities are closer to suppliers, workers and customers, while they also benefit from accessing specialist skills and a common labour pool. The literature supporting the benefits of agglomeration and clustering policy is well developed through the seminal works of Porter (1990), Krugman (1991) and 
Glaeser (2011), with increased levels of economic activity driven through increases in efficiency and productivity. Sassen (2011) is one of many researchers who has stressed the emergence and economic importance of major urban regions as dominant economic entities in the emerging global economy.

Successful cities attract talented young highly skilled workers, are centres of innovation and entrepreneurship and are competitive locations for global and regional headquarters. The proximity of universities to research and production facilities means cities are where new products are developed and commercialised... Cities benefit from advantages such as more diversified economic base with higher specialisation in productive activities, a strong innovative capacity (more than $81 \%$ of OECD patents are filed by applicants located in urban regions), and a higher level of skills. (OECD, 2006).

Successful cities bring about positive spillover effects on surrounding regions and the country as a whole (Forfás, 2009). This is especially true of the Dublin region, which is now one of the top ten destination cities for foreign direct investment (FDI) projects in the world (IBM, 2014) The Department of Jobs, Enterprise and Innovation, in their policy statement on FDI in 2014, stated that 'Dublin is competing directly with major cities in Europe and beyond for these resources, as more and more the locus of competition for FDI is amongst global cities rather than countries'. The main alternatives to Dublin are not Cork, Galway or Limerick, but Amsterdam, Manchester or Zurich. As the IDA observes, 'frequently competition for FDI comes not from other countries but from city populations in excess of 1 million people' (Dáil Éireann, 2010).

Dublin is highly integrated into the world city network through the networks of advanced producer services that are located in the city and is classified as an alpha (minus) city, which is 'a very important city that links major economic regions and states into the world economy' (Taylor, 2010). World cities such as Dublin have become centres for the production and consumption of advanced producer services in areas such as accounting, advertising, finance, insurance and law.

While cities benefit from economies of scale, they also can be victims of diseconomies of scale where growth occurs without full and targeted implementation of adequate urban and regional growth strategies and investment (OECD, 2006). Urban sprawl, congestion, 
air pollution, noise, housing affordability, and problems of crime and antisocial behaviour can significantly reduce the competitiveness and attractiveness of cities, meaning that cities require considerable investment in both hard and soft infrastructure to ensure an enhanced quality of life. 'City regions face real challenges in maintaining their competitive position and supporting economic growth that benefits all citizens, while simultaneously delivering a high quality of life and an acceptable environmental footprint' (Keegan, 2015). For example, it has been calculated by the Dublin regional housing supply force that over $€ 240$ million needs to be spent on critical infrastructure in order to cater for the construction of 80,000 new housing units (Kelly, 2014).

The key benefits of cities are concentration of talent and skills, educational institutes, ideas and creativity, which result in higher levels of innovation and knowledge creation. A broad range of 'quality of life' issues are essential in attracting employees to cities, with factors such as cultural diversity and openness becoming important differentiators for cities (British Council, 2008; Florida, 2010). The National Competitiveness Council identified the areas of superior city planning, high-quality urban design and iconic architecture as enhancing competitive city brands (2009).

Ireland has embraced the opportunity that globalisation brings and is now one of the most globalised nations in the world (E\&Y, 2012). The UN-Habitat highlights the emergence of world cities as hubs of ICT, finance and transport, driven by urbanisation pressures and competing in a borderless global domain. Cities essentially are 'the nexus of global financial markets, information societies, innovation and creativity' (UN-Habitat, 2012).

\section{Ireland: From rural to urban - Dublin's evolution as a global city}

Urban areas in Ireland now account for 62 per cent of the total population in Ireland, yet cover just 2.4 per cent of the total land area (Central Statistics Office, 2012). This contrasts to 75 per cent across the euro area and 80 per cent across the OECD (World Bank, 2014). The urban population of Ireland has grown by almost 11 per cent between 2006 and 2011, compared to just 4.6 per cent in rural areas, and now accounts for 2.84 million people (Central Statistics Office, 2012). The urban landscape of Ireland is dominated by Dublin and its suburbs (the contiguous urban area), with a 39 per cent share of the total urban population (1.1 million persons), yet it occupies just 19 per 
cent of the total urban land area in the state (Central Statistics Office, 2012). The dominance of Dublin contrasts with Cork and its suburbs, with a population of just under 200,000, while Limerick, Galway, Waterford and their suburbs had a combined total of just 220,000 persons in 2011.

Urban development in Ireland is dominated by Dublin as Ireland's capital city and gateway to Europe. The Dublin economic region extends beyond the boundary of Dublin and well into the adjoining counties of Meath, Kildare and Wicklow. Its importance in the national economy cannot be overemphasised as the Dublin and Mid East regions account for a combined share of 49.6 per cent of national GDP (Central Statistics Office, 2015). Dublin's success brings important spillover benefits to the surrounding region and Ireland as a whole (Foley et al., 2012). Despite the economic recession, Dublin was ranked the fourteenth-highest performer by GDP per capita out of 200 cities in the Brookings Metromonitor (Brookings, 2012a).

Dublin's development path from a post-industrial city into a successful, modern, multicultural city has been made possible as a result of targeted policy and planning interventions from the 1980s taking advantage of the opportunities of agglomeration economies and clustering of economic activities (Williams, 2001). The Dublin economy is now dominated by internationally traded services (particularly ICT and financial services), which have been aided by FDI-led regional development policies (Grimes \& White, 2005). The rejuvenation of the inner city from the 1990s has reversed a prolonged period of decline, with the population of the inner city having increased by 63 per cent between 1991 and 2011 (Williams et al., 2012b). Similar trends of inner city population growth are playing out internationally. In the US, for example, more Americans are now moving to cities and reversing the long-term suburban exodus (Westcott, 2014).

Landmark development schemes such as the Irish Financial Services Centre and the development of the wider docklands area have enabled Dublin to emerge as a global financial services hub, as well as a global technology hub (Newham, 2015). This emergence of inner-city areas as knowledge and innovation hubs is captured in a Harvard Business Review paper on 'the rise of urban innovation districts', which argues that the geography of innovation is shifting back into cities (Katz \& Wagner, 2014). For example, Google has shifted their R\&D and innovation-oriented activities into innovation districts such as London's tech city and New York's Chelsea district. 
Many other companies, especially technology firms, have also followed suit in this relocation trend.

Google's decision in 2004 to locate their EU headquarters in the Docklands in Dublin was a 'game changer' which subsequently led to the emergence of the docklands as a global technology hub (Newham, 2015). A wave of leading tech companies such as Airbnb, Twitter, LinkedIn and Facebook have all followed suit, with the area now commonly known as 'Silicon Docks'. Bruce Katz from the Brookings Institute defines these areas as 'innovation districts': 'geographic areas where leading edge anchor institutions and companies cluster and connect with start-ups, business incubators, and accelerators. Compact, transit accessible, and technically wired, innovation districts foster open collaboration, grow talent and offer mixed use housing office and retail' (Katz \& Wagner, 2014).

\section{The cost of Dublin's success}

The rapid growth of the wider Dublin City Region and outward expansion over the past two decades have unfortunately come at a price. Since 1971 the Dublin region has been losing a share of population to the other counties that comprise Leinster (Meredith, 2007). Much of this development has been of a sprawl-like pattern and often discontinuous in nature (Davy Stockbrokers, 2004; Williams \& Shiels, 2002; Williams et al., 2007, 2010). The housing market, and an ineffective planning system, drove first-time homebuyers further and further out of the city to low-density settlements with poor provision of services (Williams \& Sheils, 2002).

The improvement in the road network and connectedness of Dublin to a national network of motorways have dramatically reduced travel times. However, they have also resulted in the acceleration of sprawl, making it possible to live increasingly farther away from city centres with few public transport options available for residents in these outer suburban areas (Williams \& Shiels, 2002). A European green city benchmarking report shows Dublin as being one of the worst-performing cities in relation to public transport users across all European capital cities (Siemens, 2009).

Traditionally, administrative boundaries are used to define city regions; however, their extent does not often align with these administrative boundaries - for example, the functional urban region of Dublin, which extends out to the midlands in particular. This results in fragmented governance structures which challenge the delivery of 
optimal policies for economic development and delivery of vital infrastructure for these regions (Williams, 2001). Appropriate mechanisms need to be developed at a suitable regional level to ensure an organising capacity exists to plan and implement economic development policy. This is particularly important as the future population growth of Ireland is expected to concentrate around the Dublin City Region, with a projected increase of between 96,000 and 286,000 by 2031, while the population of the Mid-East is set to increase by between 78,000 and 144,000 over the same period (Central Statistics Office, 2013). This pattern of growth is likely to put increasing pressure on infrastructure and public service needs, which may negatively impact Dublin's future competitiveness if not managed properly.

\section{The role of spatial planning}

The evolution of city regions in the Irish context and Dublin's growth as Ireland's only city of international scale and significance have happened in the absence of a long-term, coherent spatial plan. The lack of appropriately sized secondary cities to act as a counterbalance to Dublin's dominance is a topic that has generated much debate (Hughes, 2013). A recent blog post entitled The Need for Lumpiness in Balanced Regional Development highlights the challenge of implementation of EU balanced regional development in the Irish context as this is based on the underlying, necessary assumption that there already exists a second tier of cities (Hughes \& Sirr, 2015).

The situation may have been a lot different had the state's first modern spatial development plan - the Buchanan plan (Colin Buchanan \& Partners, 1968) - been implemented. This plan proposed to concentrate industrial-led growth into Cork and Limerick, with major growth targets proposed for these cities. It was to be delivered through an accompanying, intensive house-building programme, with modest growth targets for Dublin that would be limited to its natural increase. However, the Buchanan plan was rejected by a rural, centric political corpus within eighteen months of its inception by the Department of Finance (Meredith \& van Egeraat, 2013).

A scattergun approach to development ensued where, over a period of twenty successive years, Irish governments avoided the 'hot potato' of implementing national and spatial planning (Hughes, 2013). The NSS was the first real attempt to direct regional development, responding to growing regional imbalances in socio-economic 
development during the first phase of the Celtic tiger period in the 1990s (Meredith \& van Egeraat, 2013). Its principal objective was to promote balanced regional development by way of twenty-two gateway and hub settlements, in addition to Dublin. The NSS envisaged the consolidation of the existing Dublin metro region.

The results of the 2011 census highlighted the failure of the NSS to concentrate population growth in particular areas. Its downfall was down to the fact that it was never implemented properly due to a lack of political and administrative commitment. The programme of public sector decentralisation announced by the then Minister for Finance in the budget of 2003 weakened the NSS (Minihan, 2014), and the economic recession of 2007 ensured that it would not be possible to implement the NSS in its current form.

The Department of the Environment, Community and Local Government is currently in the process of devising a new policy approach to regional development. As Ireland emerges from the recession and enters a new period of growth, there is a need for a coherent plan that supports not only an internationally competitive Dublin City Region but also a number of viable counterbalances. A new spatial strategy needs to focus on developing at least 'one city or large urban centre in every planning region ... which captures the benefits of urban agglomeration growth with its attendant clustering effects' (Hughes \& Sirr, 2015). This will ensure that Ireland's cities can continue to compete in an increasingly competitive global landscape. 'The principle guiding regional development should be about maximising the inherent growth potential of each region, not re-directing economic growth away from Dublin' (Thornhill, quoted in Dublin Regional Authority, 2007).

\section{Local authority context: Supporting city region development}

A key function of local government is to respond to the needs of residents and to set local priorities accordingly (Local Government Management Agency, 2015). Policies that are designed at a national level have to fit into very different conditions locally. For example, the needs of a growing city region like Dublin differ drastically from those of a rural town setting. Local government in Ireland has responsibility for aspects of housing and roads, planning, environmental protection, provision of recreation and amenities, and community infrastructure. This contrasts to the situation in other OECD countries where they have responsibility for a much broader range of services, including 
primary and secondary education, health, social welfare, care of the elderly and childcare services, public transport, policing and local economic development (Callanan, 2003). Irish local government also differs from other European countries in that its expenditure as a proportion of public expenditure and GNP is low in comparison (Dollard, 2003). It has little in the way of tax-raising powers compared to many other European countries and has a lack of real autonomy (Boyle et al., 2003).

These combined factors reduce the impact that local government can have in delivering truly effective local development that is tailored to the needs of the region. It also puts Irish regions at a disadvantage to their international counterparts. A series of reports on local government reform have made recommendations to move towards a wider range of locally delivered services with appropriate funding mechanisms. Few of these recommendations have been adopted (Dublin City Council, 2008; Indecon, 2005). Furthermore, the transition of water services to Irish Water, which commenced in 2010, represented a further perceived weakening of local government. It is argued that local government in Ireland does not have the powers and controls to deliver effectively at a local level, which has resulted in a more challenging environment for the optimal management of our city regions - in particular Dublin. O'Brien (2007) asks whether 'it is possible for Dublin, as an evolving city-region in an open global economy, to meet the challenges that are likely to arise in the coming years'.

This Irish experience of regional governance can be contrasted with a shifting policy agenda in the UK towards localism. 'If we want our cities to be able to compete on the global stage then we have to start locally. That's why we are putting decisions on growth in the hands of local leaders and business who understand their local economy' (Department of Community and Local Government, 2011). The UK Government has set out plans to give English cities greater powers in order to spread out growth beyond London. This includes increased power over areas such as housing, transport and policing, as well as the establishment of a 'greater Manchester authority' and a directly elected mayor (Wintour, 2014).

As part of the Local Government Reform Act, 2014, a proposal for a directly elected mayor for Dublin did not proceed to a public plebiscite even though a combined total of Dublin councillors voted 98-19 in favour. Despite high levels of support, the proposal was vetoed by Fingal County Councillors. However, there was a general 
consensus that the Local Government Reform Act, 2014, did not provide enough detail about the role and powers of the mayor (Quinlivan, 2014).

Despite the limitations of the Irish local government system, it still plays an important role in socio-economic development through the provision of services and also as purchaser of goods and services, with a total budget of $€ 3.91$ billion (revenue) in 2015 (Department of the Environment, Community and Local Government, 2015). Local authorities play a key role in economic development, providing much of the physical infrastructure in our cities, which supports enterprise and promotes employment. This includes the delivery of large-scale engineering projects in the areas of roads, transport, waste and housing. It also has responsibility for the planning and development brief though development plans and, in some cases, strategic development zones. The importance of local planning and development is highlighted by the IDA as key to ensuring that 'Ireland's capital city creates a world-class urban area that continues to attract not only international investment but also international talent'. It also highlights the importance of maintaining attractive regional cities and towns, as 'these urban centres will play an important part in attracting FDI to all regions' (IDA, 2015).

An overview of the actions delivered by local authorities to support job creation and to promote economic development was developed in response to the Action Plan for Jobs 2012 and captured over 2,400 activities in 2012 (County and City Managers' Association, 2013). Activities included infrastructure development, organising and supporting festivals, provision of recreation/amenity facilities, economic promotion, financial incentives, enterprise infrastructure and establishment of collaborative structures focusing on economic development. While the list of actions is comprehensive, there is, however, little detail on the full impact and cost-benefits of such investments.

\section{City region growth initiatives supporting the economic recovery}

Despite the absence of formal structures to cooperate on economic development, the Dublin region has collaborated to build on Dublin's wider economic potential (in many cases this was led by Dublin City Council). This enhanced cooperation was triggered as a result of the economic recession in 2007. For example, in recognition of the 
changing roles of city regions, the Dublin City Manager, John Tierney, established the Office of International Relations and Research in 2007 to enhance Dublin's global position through participation in international networks, as well as the hosting of international delegations. This also involved the development of a multi-year research program to better understand Dublin's international performance and position in global city benchmarks (O'Brien, 2008).

The city and county managers in the Dublin local authorities, along with the Dublin regional authority, collaborated to deliver a number of key economic priorities as part of the Economic Development Action Plan for the Dublin City Region. A dedicated economic development unit (EDU) was created within the planning directorate of Dublin City Council in 2009 to support delivery of this action plan. This plan set out thirty-five key actions for the development of Dublin as an internationally competitive city region (Dublin City Council, 2009). Its aim was to 'position the Dublin City Region, the engine of Ireland's economy, as a significant hub in the European knowledge economy through a network of thriving sectoral and spatial clusters providing a magnet for creative talent and investment'. There was, however, little monitoring and measurement of the impact of these actions over the life cycle of the plan.

\section{Creative Dublin Alliance}

The EDU in Dublin City Council also had responsibility for the management of the CDA, which was to play a significant role in delivering on regional economic initiatives through the recession period. Established in 2008 during a time when the economy was in freefall, it was a regional mechanism to ensure a more coordinated economic development approach to drive city region initiatives. Members were drawn from the most senior level in local government, business, universities, state agencies and the not-for-profit sector. It was a 'triple helix' model for the city region focused on strengthening Dublin's position as a 'global' hub for innovation. The CDA aimed to help identify, discuss, recommend, distribute and implement solutions in response to the economic challenges that Dublin faced in becoming a more competitive city internationally (Pivot Dublin, 2011).

An example of the type of projects that were developed under the CDA banner was the delivery of an annual festival called Innovation Dublin, which brought together the public, private, academic and notfor-profit sectors to exhibit innovative projects and solutions that were being developed in Dublin during a time when much of the emphasis 
was on negative issues. Launched in 2009 and coordinated by Dublin City Council, it continued over a four-year period, having built up strong momentum and participation across multiple stakeholders.

The establishment of Dublinked, a regional 'open data' initiative to facilitate data-driven innovation, released local government data sets in areas such as planning, transport and waste (see www.dublinked.ie). This project was a precursor to attracting the IBM Smarter Cities lab to Dublin with the creation of over $200 \mathrm{R} \& \mathrm{D}$ positions. The Dublinked initiative has been cited by PWC (2014) and Urbact (2015) as a best-practice example of urban innovation.

The CDA project was a unique partnership in the Irish context, setting the benchmark for new ways of working and collaboration in the city region (New York Innovation Exchange, 2011). While solid progress was made, it proved challenging to maintain active and equal engagement of all members, resulting in a deficit of funding and resources to deliver on the extensive array of projects that had been initiated. While there were some successes, it operated on a goodwill basis from each of the partners and Dublin City Council, and was discontinued in 2015.

Despite this, the CDA has been highlighted as a very positive development (O'Brien, 2007). However, it was not without its detractors as many key stakeholders across Dublin felt there was a 'lack of knowledge of the impact of the CDA and the projects it was delivering' (Foley et al., 2012). There was a view from the OECD that the CDA and the Economic Development Action Plan focused too much on national and global developments rather than on local employment sectors. There was a 'a particular challenge to exercising strategic leadership in the Dublin region due to the large number of organisations and sectors that impact on the performance of the city's economy' (OECD, 2014b).

\section{Activating Dublin}

Another project that was to emerge towards the end of the recession in 2012 was Activating Dublin, a joint initiative of the Dublin Chamber of Commerce, Dublin City Council, central government, and stakeholders from the private, public and social sectors. The aim was to support economic growth and employment opportunities in the Dublin region and transform Dublin from a good international city to a great one to live, work and visit.

The starting objectives of Activating Dublin were to: 
- develop a vision for the Dublin region which builds on comparative advantages, with specific initiatives along the areas of economic development, sustainability and quality of life;

- create action plans to deliver on these initiatives, outlining specific actions to make the vision a reality, and identifying potential owners and drivers; and

- develop a delivery mechanism to support these initiatives meaningfully over the long term.

Activating Dublin had the advantage of good timing, as Ireland was escaping the economic crisis, and there was an emphasis on targeted projects with clear and defined outcomes. The projects were progressed through a project management office (which included Dublin Chamber and Dublin City Council staff co-located in the Dublin Chamber) with bi-weekly reporting to a strategic board. This included the secretary general of the Department of Finance, the CEO of Dublin Chamber, the CEO of Dublin City Council, the vice president of Google EMEA, the MD of The Irish Times, the CEO of Focus Ireland, the MD of McKinsey Ireland, the former chair of Accenture Global and the head of RTE Digital.

The focus of Activating Dublin was on projects that the three partners (local and central government, and business) were uniquely able to help with and align to their own strategies. The following projects were delivered through this process:

i. Activating Dublin Online project, which was a four-month pilot programme to help Irish companies develop a more effective online trading presence. Delivered by eBay, Facebook, Google and PayPal, this was the first time globally that these four companies had worked together in this way (Hyland, 2013).

ii. Startup Community project: Through engagement with the tech start-up community across Dublin, this involved the delivery of a strategic blueprint for developing the Dublin start-up ecosystem. The report (Activating Dublin, 2013) identified a number of key actions to support Dublin's start-up scene and helped secure private-sector funding to recruit a Dublin start-up commissioner (Molloy, 2014). This is contributing to making Dublin the best place in Europe to start and grow a tech business, and helping Dublin to be recognised as the innovation hub where companies will start up, scale faster, create long-term sustainable jobs and add value to the economy. This work was recognised by the 
OECD: 'Activating Dublin has high-level representatives of central and local government and enterprises seeking to do just that to boost Dublin's already existing computer software cluster and start-up community and increase Dublin's international reputation' (OECD, 2013).

Activating Dublin is building out initiatives in the areas of youth unemployment, smart cities and the international promotion of Dublin. The World Chambers of Commerce shortlisted Activating Dublin as a best-practice example of a Chamber of Commerce advocacy project (Dublin Chamber of Commerce, 2015).

\section{Enhancing the role of local government in economic development}

The publication of Putting People First in 2012 and the subsequent implementation of the Local Government Reform Act, 2014, set out an enhanced economic development role for local government. The government vision of this reform was for 'local government to be the engine behind recovery' (Kelly, 2015). Local authorities have much greater potential to promote and facilitate economic development and to oversee the local implementation of the government's action plan for jobs. As part of this reform process local enterprise offices are now in place to act as one-stop shops to deliver enterprise supports through the local government system. Local authorities will develop six-year local economic and community plans, which will involve the identification of high-level goals and specific objectives and actions. A key feature will also be the establishment of an ongoing monitoring and reporting system - something that has been notably absent in recent times. A local community development committee will represent and align both community and economic development interests. This addresses the 'disconnect between local community and economic development' and the 'lack of structured communication between local employment services and bodies promoting regional economic development' (OECD, 2014a).

Furthermore, the launch of the first Dublin Quarterly Economic Monitor, a joint initiative of the four Dublin local authorities, is the first of its kind to look exclusively at the Dublin City Region. This report tracks fifteen key economic indicators, capturing data from the height of the boom to the economic crash and the subsequent recovery. The decision to commission the Dublin Quarterly Economic 
Monitor reflects the enhanced role of local authorities in the area of economic development and enterprise support, in line with the local government reform programme (Dublin City Council, 2015a).

\section{Conclusion}

There is a comprehensive evidence base that demonstrates the growing influence of city regions in the global economy (Ratcliffe \& Krawczyk, 2004; Rockefeller Foundation, 2009). This is not a new phenomenon, as cities, not nations, were the original global commercial nodes before the rise of the nation state (Brookings, 2012b). However, the twenty-first century is becoming known as the century of the city where city regions are increasingly influential and, in some cases, dominate their national economies (Dublin Chamber of Commerce, 2012). This leads to challenges in accomplishing balanced regional development targets and in turn creates urban-rural political tensions, which is very evident in the Irish context. Newspaper headlines such as 'Urban-rural divide widens as capital booms' (Weston, 2015), 'Small towns face "struggle to win investment"' (2003) and 'Rural areas can no longer depend on the IDA to save them' (Curren, 2015) capture this sentiment. The reality is that city regions are competing strongly for mobile investment, talent and tourism, with investment decisions being made between cities and not countries (Economist Intelligence Unit, 2012). Ireland's best chance of securing FDI is frequently through its capital city, where competition is 'from city populations in excess of 1 million people' (Dáil Éireann, 2010). Cork, Galway and Limerick also perform strongly in this regard; however, they do not have the scale and economic diversity to compete internationally at the same level as Dublin.

Dublin is highly embedded into the global economy and is now recognised as a successful, modern, multicultural, world-class city. Dublin's growth and success, however, has come at a price, with an associated urban sprawl due to unsustainable planning and development patterns (Williams et al., 2012). It is argued that Ireland has not developed appropriately sized second-tier cities to act as a counterbalance to Dublin (Hughes, 2013). The cities that would be most suitable to play such a role based on economic potential include Cork, Galway and Limerick (Foley et al., 2012). The absence of suitably sized second-tier cities is a result of a lack of political will to implement spatial-planning policies that are evidence led and take advantage of the established economic benefits of urban agglomera- 
tion and clustering theory. The failure of the most recent NSS is a prime example of this, while in the $1960 \mathrm{~s}$ it was the nonimplementation of the Buchanan plan. Whatever the successor will be to the NSS, it will need to 'take account of our wider island, European and global contexts' (Coffey, 2015).

Local government in Ireland, despite its very limited powers, plays a key role in managing the quality of the urban environment and overall liveability of the city. These are key differentiators in relation to competitiveness. The new framework for local and community development, as set out in the Local Government Act, 2014, is welcome as it attempts to align national, regional and local economic development (OECD, 2014a). Prior to this, Dublin City Region initiatives such as the development of the Economic Development Action Plan for the Dublin City Region, the CDA and Activating Dublin were developed on a goodwill basis to deliver projects that supported the regional economy and enhance the international competitiveness of Dublin. There have been many successful outcomes, which include the establishment of a Dublin Start-up Commissioner and the Dublin region open-data initiative, Dublinked. However, there has been a notable absence of monitoring and impact evaluation for many of these regional-based economic development initiatives. Moving forward, it is essential that the development of future local economic and community action plans and associated projects are properly monitored and evaluated, and that a strong evidence-based approach is taken (OECD, 2014a).

The launch of the first Dublin Quarterly Economic Monitor in April 2015, which monitors fifteen key economic indicators across the Dublin region, is a positive development (Dublin City Council, 2015a).

There are question marks about whether the current governance model for Dublin and city regions in Ireland is enabling them to perform to their optimal levels. The example in the UK of localism and plans to give English cities greater powers 'to help their cities to compete on the global stage' will be important to monitor. While the Dublin mayoral process initially failed, there was a consensus that more detail on the role and powers of the mayor needs to be considered. There is mixed opinion on this topic but it certainly is an area that requires further consideration.

Despite well-intentioned plans for local government to take a greater role in economic development, the simple fact is that local government does not have responsibility for many of the instruments required to drive economic development. 'City regions face real 
challenges in maintaining their competitive position and supporting economic growth that benefits all citizens, while simultaneously delivering a high quality of life and an acceptable environmental footprint' (Keegan, 2015). Policymakers and politicians must ensure that Ireland's city regions can address these challenges, and furthermore can compete successfully on a global stage. In order to achieve this they require the appropriate tools and powers. Failure to address these deficiencies will seriously impact the future economic competitiveness of Ireland.

\section{Background}

The author has managed a multi-year research programme that benchmarked the performance of the Dublin City Region. Working with organisations such as Urbact, McKinsey, The Brand Union, Mercer, GACP, Cambridge Econometrics, British Council, Z/Yen, UCD and Leading Cities, he has developed an in-depth knowledge of how cities measure and monitor their international competitiveness. In 2012 he collaborated on a one-year research project with UCD on 'Dublin's Role in the National and Global Economy'. He has published a number of policy papers in relation to new urban economies, open data and the economic evolution of Dublin. He supported the work of the CDA on the importance of developing a city brand for Dublin. From 2012 to 2014 he was seconded to the Dublin Chamber of Commerce to support the delivery of Activating Dublin. He now works with the Chief Executive of Dublin City Council, leading on the city council's smart city initiative while also managing the delivery of Dublin's Quarterly Economic Monitor. He has a unique perspective on the role of cities and how they drive competitiveness, having collaborated with cities across the globe, and is enthusiastic about the potential of Ireland's cities, and in particular Dublin, to drive future economic growth.

\section{References}

2thinknow. (2014). Innovation cities index. Retrieved from http://www.innovation-cities.com/innovation-cities-index-2014-global/8889 [10 July 2015].

Activating Dublin. (2013). A report on maximising the potential of the tech startup ecosystem in Dublin. Retrieved from http://www.dubchamber.ie/ docs/newsletters/best-place-to-start-activating-dublin-tech-startupreport.pdf [10 July 2015]. 
A. T. Kearney. (2015). Global cities index. Retrieved from https://www. atkearney.com/research-studies/global-cities-index/2015 [15 June 2015].

Barber, B. R. (2013). If mayors ruled the world: dysfunctional nations, rising cities. New Haven: Yale University Press.

Beehner, L. (2014, February 24). Should mayors rule world? Retrieved from http://www.usatoday.com/story/opinion/2014/02/24/mayors-rob-fordgarcetti-booker-politics-washington-column/5787987/ [10 July 2015].

Boyle, R., Humphreys, P. C., O’Donnell, O., O'Riordan, J., \& Timonen, V. (2003). Changing local government: $A$ review of the local government modernisation programme [CPMR Research Report 5]. Dublin: Institute of Public Administration.

British Council. (2008). Towards open cities. Retrieved from http://www. opencities.eu/web/download/conference/towards_opencities.pdf [10 July 2015].

Brookings. (2012a). Global metromonitor, volatility, growth, and recovery. Retrieved from http:/www.brookings.edu/ /media/research/files/reports/ 2012/1/18-global-metro-monitor/0118_global_metro_monitor.pdf [10 June 2015].

Brookings. (2012b). Metropolitan policy programme. Metro trade: Cities return to their roots in the global economy. Retrieved from http://www.brookings. edu/ /media/research/files/papers/2012/11/26-metro-trade/26-metrotrade.pdf [10 June 2015].

Brookings. (2015). Global cities initiative: Brookings Institute and JPMorgan Chase Bank. Retrieved from http://www.brookings.edu/about/projects/ global-cities [10 June 2015].

C40. (2015). Powering climate action: Cities as global changemakers. Retrieved from http://issuu.com/c40cities/docs/powering_climate_action_full_report [10 July 2015].

Callanan, M. (2003). The role of local government. In M. Callanan \& J. Keogan (Eds), Local government in Ireland. Dublin: Institute of Public Administration.

Carbon Disclosure Project. (2010). The case for city disclosure. Retrieved from https://www.cdp.net/en-US/Programmes/Documents/Case-for-CityDisclosure.pdf [10 June 2015].

Central Statistics Office. (2012). Census highlights part 1. Retrieved from http://www.cso.ie/en/media/csoie/census/documents/census2011pdr/Census ,2011,Highlights,Part,1,web,72dpi.pdf [10 July 2015].

Central Statistics Office. (2013). Regional population projections 2016-2031. Retrieved from http://www.cso.ie/en/releasesandpublications/er/rpp/ regionalpopulationprojections2016-2031/\#.VYhPGvn48-U [10 June 2015].

Central Statistics Office. (2015). County incomes and regional GDP 2012. Dublin: Central Statistics Office.

Coffey, P. (2015). Address by Minister Paudie Coffey at the Irish Planning Institute Annual Conference 2015. Retrieved from http://www. merrionstreet.ie/en/News-Room/Speeches/Address_by_Minister_Paudie 
Coffey_at_the_Irish_Planning_Institute_Annual_Conference_2015.html [15 July 2015].

Colford, C. (2013, July 25). Competitive cities: Driving productivity and prosperity. Retrieved from http://blogs.worldbank.org/psd/competitivecities-driving-productivity-and-prosperity [10 June 2015].

Colin Buchanan \& Partners. (1968). Regional studies in Ireland. Dublin: An Foras Forbartha.

County and City Managers' Association. (2013). Local authorities supporting economic development. Retrieved from http://www.lgma.ie/en/news/ccmareport-local-authorities-support-economic-development [10 July 2015].

Curren, R. (2015, April 24). Rural areas can no longer depend on the IDA to save them. Retrieved from http://www.independent.ie/opinion/comment/ rural-areas-can-no-longer-depend-on-ida-to-save-them-31167368.html [10 June 2015].

Dáil Éireann. (2010). Adjournment debate: Job Creation. 26 May. Dáil Debates, 710 (2).

D'arcy, C. (2015, January 2). Fears of favouritism as Dublin included in regional assembly. Retrieved from http://www.irishtimes.com/news/politics/fears-offavouritism-as-dublin-included-in-regional-assembly-1.2052491 [15 July 2015].

Davy Stockbrokers. (2004). Crawling through the sprawl: Commuting patterns, urban form and public transport in Dublin. Dublin: Davy Stockbrokers.

Department of Community and Local Government. (2011). Government renews focus on cities. Retrieved from https://www.gov.uk/government/ news/government-renews-focus-on-cities-2 [10 June 2015].

Department of Jobs, Enterprise and Innovation. (2014). Policy statement on FDI in Ireland. Retrieved from http://www.djei.ie/publications/ enterprise/2014/Policy_Statement_FDI_Ireland_July_2014.pdf [10 June 2015].

Department of the Environment, Community and Local Government. (2012). Putting people first: Action programme for effective local government. Dublin: Department of the Environment, Community and Local Government.

Department of the Environment, Community and Local Government. (2015). Local authority budgets, 2015. Retrieved from http://www.environ.ie/en/ LocalGovernment/LocalGovernmentReform/News/MainBody,40085, en.h tm [24 May 2015].

Dollard, G. (2003). Local government finance: trends in revenue and expenditure. In M. Callanan \& J. Keogan (Eds), Local government in Ireland: Structures, functions and developments. Dublin: Institute of Public Administration.

Dublin Chamber of Commerce. (2012). The world is not flat: The case for city regions. Retrieved from http://www.dubchamber.ie/docs/policy-reports/thecase-for-city-regions-full.pdf [10 July 2015].

Dublin Chamber of Commerce. (2015). Dublin Chamber shortlisted for global advocacy award. Retrieved from http://www.dubchamber.ie/news/press- 
releases/news/display-news/2015/04/16/dublin-chamber-shortlisted-forglobal-advocacy-award [15 July 2015].

Dublin City Council. (2008) Funding the Dublin City region. Dublin: Dublin City Council.

Dublin City Council. (2009). Economic development action plan for the Dublin City Region. Retrieved from http://www.dublincity.ie/sites/default/files/ content/YourCouncil/CouncilPublications/Documents/Dublin_Region_Ec onomic_Action_Plan_-_Lo_Res.pdf [10 July 2015].

Dublin City Council. (2015a). Dublin quarterly economic monitor. Retrieved from https://www.localenterprise.ie/DublinCity/Publications-Resources/ Dublin-Economic-Monitor/ [10 July 2015].

Dublin City Council. (2015b). Dublin local economic development plan (2016-2021). Retrieved from https://consultation.dublincity.ie/admin/lecp [10 July 2015].

Dublin Regional Authority. (2007). Enterprise strategy for the Dublin City Region. Retrieved from http://www.dra.ie/dynamicdata/asset/09\%20Sept $\%$ 20FINAL \%20Enterprise \%20Strand\%20document.pdf [5 May 2015].

E\&Y. (2012). Globalisation index. Retrieved from http://www.ey.com/ GL/en/Issues/Driving-growth/Globalization--Looking-beyond-theobvious--2012-Index [10 June 2015].

Economist Intelligence Unit. (2012). Hotspots 2025: Benchmarking the future competitiveness of cities. Retrieved from http://www.citigroup. com/citi/citiforcities/pdfs/eiu_hotspots_2012.pdf [10 June 2015].

Florida, R. (2010). Who's your city?: How the creative economy is making where to live the most important decision of your life. Toronto: Vintage Canada.

Foley, W., Williams, B., \& Cudden J. (2012). Dublin's role in the national and global economy: Report 3 - Main report on key indicators and opinion on national and global trends. Retrieved from http://www.dra.ie/dynamic data/asset/Presentation\%20October\%2026\%20to\%20Dublin\%20Forum.p df [15 July 2015].

Forfás. (2009). Our cities: Drivers of national competitiveness. Dublin: Forfás/National Competitiveness Council.

Geoghegan, T. (2013, August 14). Is the New York mayor the most powerful in the world? Retrieved from http://www.bbc.com/news/magazine-23626980 [20 July 2015].

Glaeser, E. (2011). Triumph of the city - How our greatest invention makes us richer, smarter, healthier and happier. New York: Penguin Press.

Government of Ireland. (2002). The national spatial strategy 2002-2020: People, places and potential. Dublin: The Stationery Office.

Grimes, S., \& White, M. (2005). The transition to internationally traded services and Ireland's emergence as a successful European region. Environment and Planning A, 37, 2169-88.

Hughes, B. (2010). The Greater Dublin Area: Ireland's potential city-state of the early 21st century. Doctoral Thesis, Dublin Institute of Technology. 
Hughes, B. (2013). Settlement selection: A critical consideration for a new spatial strategy plan? MSc thesis, Dublin Institute of Technology.

Hughes, B., \& Sirr, L. (2015, April 28). The need for lumpiness in balanced regional development. Retrieved from https://irelandafternama.wordpress. com/2015/04/28/the-need-for-lumpiness-in-balanced-regional-develop ment/ [10 June 2015].

Hyland, P. (2013, April 26). New scheme launched to help get more businesses trading online. Retrieved from http://businessetc.thejournal.ie/tradingonline-sme-activating-dublin-facebook-google-paypal-886009-Apr2013/ [10 July 2015].

IBM. (2014). Global location trends 2014 annual report. Retrieved from http://www-01.ibm.com/common/ssi/cgi-bin/ssialias? subtype $=$ XB\&infotype $=$ PM\&appname $=$ GBSE_GB_TI_USEN\&htmlfid $=$ GBE03 629USEN\&attachment $=$ GBE03629USEN.PDF [10 June 2015].

IBM. (2015). Smarter cities. Retrieved from http://www.ibm.com/smarter planet/ie/en/smarter_cities/overview/ [15 July 2015].

IDA. (2015). Winning: Foreign direct investment 2015-2019. Retrieved from http://www.idaireland.com/en/docs/publications/IDA_STRATEGY_FINA L.pdf [15 July 2015].

Indecon. (2005). Review of local government financing. Dublin: Indecon.

ISO. (2014). ISO 37120:2014 Sustainable development of communities Indicators for city services and quality of life. Retrieved from http://www.iso. org/iso/catalogue_detail?csnumber=62436 [10 May 2015].

Jones Lang La Salle. (2013). The business of cities 2013: What do 150 city indexes and benchmarking studies tell us about the urban world in 2013? Retrieved from http://www.jll.com/Research/jll-city-indices-november2013.pdf [10 July 2015].

Katz, B., \& Wagner, J. (2014). The rise of urban innovation districts. Retrieved from https://hbr.org/2014/11/the-rise-of-urban-innovation-districts [10 June 2015].

Keegan, O. (2015). Dublin quarterly economic monitor, Q1 2015. Retrieved from https://www.localenterprise.ie/DublinCity/Publications-Resources/ Dublin-Economic-Monitor/DEM-Issue-1.pdf [10 June 2015].

Kelly, A. (2015). Local government to be the engine behind recovery. Retrieved from http://www.merrionstreet.ie/en/News-Room/Releases/LOCAL GOVT_TO_BE_THE_\%E2\%80\%98ENGINE_BEHIND_RECOVERY $\%$ E2\%80\%99_WITH_KEY_REFORMS_\%E2\%80\%93_MINISTER_K ELLY.html [10 July 2015].

Kelly, O. (2014, December 30). Over 80,000 homes could be built in Dublin. Retrieved from http://www.irishtimes.com/news/ireland/irish-news/over80-000-homes-could-be-built-in-dublin-if-240m-spent-on-infrastructure1.2050689 [15 June 2015].

Knight Frank. (2015). Global cities index. Retrieved from http://www. knightfrank.com/global-cities-index-2015 [15 June 2015]. 
KPMG. (2015). Global cities investment monitor. Retrieved from https://www. kpmg.com/FR/fr/IssuesAndInsights/ArticlesPublications/Documents/Glob al-Cities-Investment-Monitor-2015.pdf [15 June 2015].

Krugman, P. (1991). Geography and trade. Cambridge: MIT Press.

Lever, W. F. (2001). Charismatic urban leaders and economic development: Good mayors and bad mayors in Europe. Space and Polity, 5 (2), 113-26.

Local Government Management Agency. (2015). Local government in Ireland. Retrieved from http://www.lgcsb.ie/en/irish-local-government [15 July 2015].

Mastercard. (2015). Global destination cities index. Retrieved from http://newsroom.mastercard.com/digital-press-kits/mastercard-globaldestination-cities-index-2015/ [15 June 2015].

McKinsey Global Institute. (2011). Urban world: Mapping the economic power of cities. Retrieved from http://www.mckinsey.com/Insights/MGI/ Research/Urbanization/Urban_world [15 July 2015].

Mercer. (2015). Quality of living index. Retrieved from https://www. imercer.com/content/quality-of-living.aspx [15 July 2015].

Meredith, D. (2007). Changing distribution of Ireland's population 1996-2006: Urban/rural analysis. Dublin: Teagasc.

Meredith, D., \& van Egeraat, C. (2013). Revisiting the National Spatial Strategy ten years on. Administration, 60 (3), 3-9.

Minihan, M. (2014, July 1). McCreevy decentralisation plan unveiled hours before budget. Retrieved from http://www.irishtimes.com/news/politics/ mccreevy-decentralisation-plan-unveiled-hours-before-budget-1.1851376 [10 July 2015].

Molloy, T. (2014, September 10). Start-up czar to help kick start Dublin's tech companies. Retrieved from http:/www.independent.ie/business/ technology/news/startup-czar-to-help-kick-start-dublins-tech-companies30574549.html [15 July 2015].

National Competitiveness Council. (2009). Our cities: Drivers of national competitiveness. Dublin: National Competitiveness Council.

Newham, P. (2015). Silicon docks, the rise of Dublin as a global tech hub. Dublin: Liberties Press.

New York Innovation Exchange. (2011). Best practice: Creative Dublin Alliance - Creating the leadership consensus. Retrieved from http:/www.nyc.gov/ html/ia/gprb/downloads/pdf/Dublin_CDA.pdf [10 July 2015].

O'Brien, D. (2007). Regional governance and the challenge of managing socioeconomic change. Retrieved from http://www.uep.ie/pdfs/JIUS_ Vol7_9_2008_2010.pdf [10 July 2015].

O'Brien, T. (2008, April 5). Dublin City faces international benchmarking. Retrieved from http:/www.irishtimes.com/news/dublin-city-facesinternational-benchmarking-1.910025 [15 July 2015].

OECD. (2006). Competitive cities in the global economy. Paris: OECD. 
OECD. (2013). From bricks to brains: Increasing the contribution of knowledgebased capital to growth in Ireland [OECD Economics Department Working Papers, No. 1094]. Retrieved from http://dx.doi.org/10.1787/5k3wd358lj8ren [10 July 2015].

OECD. (2014a). Delivering local development: Ireland [OECD Local Economic and Employment Development (LEED) Working Papers]. Paris: OECD.

OECD. (2014b). Employment and skills strategies in Ireland. Retrieved from http://dx.doi.org/10.1787/9789264207912-en [10 June 2015].

OECD. (2015). OECD STAT. Retrieved from https://stats.oecd.org/ Index.aspx? DataSetCode $=$ CITIES [10 June 2015].

Pivot Dublin. (2011). Interview: Creative Dublin Alliance with Lorna Maxwell. Retrieved from http:/www.pivotdublin.com/blog/interview_with_lorna_ maxwell_of_the_creative_dublin_alliance/ [10 July 2015].

Porter, M. E. (1990). The competitive advantage of nations. Retrieved from https://hbr.org/1990/03/the-competitive-advantage-of-nations [15 July 2015].

PWC. (2014). iUrban: Innovative city strategies for delivering sustainable competitiveness. Retrieved from http://www.pwc.com/gx/en/psrc/global/ innovative-city-strategies-for-delivering-sustainable-competitiveness.jhtml [10 July 2015].

PWC. (2015). Cities of opportunity. Retrieved from http://www.pwc.com/ us/en/cities-of-opportunity/ [10 July 2015].

Quinlivan, A. (2014, May 24). The election that wasn't: How the plan for a directly elected Dublin mayor could be revived. Retrieved from http://www.irishtimes.com/news/politics/the-election-that-wasn-t-how-theplan-for-a-directly-elected-dublin-mayor-could-be-revived-1.1806976 [10 July 2015].

Ratcliffe, J., \& Krawczyk, E. (2004). Imagineering cities: Creating liveable urban futures in the 21st century. Retrieved from http://arrow.dit.ie/cgi/ viewcontent.cgi? article $=1007 \&$ context $=$ futuresacart [10 July 2015].

Rockefeller Foundation. (2009). Century of the city. Retrieved from http://www.rockefellerfoundation.org/report/century-of-the-city/ [10 July 2015].

Sassen, S. (2011). Cities in a world economy. Thousand Oaks: Sage Publications.

Siemens. (2009). Siemens green city index. Retrieved from http://www.siemens. com/entry/cc/en/greencityindex.htm [10 July 2015].

Small towns face 'struggle to win investment'. (2003, July 3). Retrieved from http://www.irishtimes.com/business/small-towns-face-struggle-to-ininvestment-1.364826 [15 June 2015].

Taylor. P. (2010). Benchmarking Dublin GaWC Project 89. Retrieved from http://www.lboro.ac.uk/gawc/projects/projec89.html [10 June 2015].

The New Climate Economy. (2014). The global commission on the economy and climate. Retrieved from http://newclimateeconomy.net/ [10 June 2015]. 
UN. (2011). Cities and climate change: Global report on human settlements 2011. Retrieved from http://mirror.unhabitat.org/downloads/docs/ E_Hot_Cities.pdf [5 June 2015].

UN-Habitat. (2012). UN-Habitat annual report. Retrieved from http://unhabitat.org/un-habitat-annual-report-2012/ [5 July 2015].

UN Population Division. (2014). World urbanization prospects (2014 revision). Retrieved from http://esa.un.org/unpd/wup/Country-Profiles/ [10 July 2015].

Urbact. (2015). The open data economy: Promoting digital innovation in Dublin. URBACT II capitalisation. Retrieved from http://urbact.eu/sites/default/ files/cs-01b_nu-dublin-f3.pdf [5 July 2015].

Westcott, L. (2014, March 27). More Americans moving to cities, reversing the suburban exodus. Retrieved from http://www.thewire.com/national/ 2014/03/more-americans-moving-to-cities-reversing-the-suburbanexodus/359714/ [10 June 2015].

Weston, C. (2015, April 24). Urban-rural divide widens as capital booms. Retrieved from http://www.independent.ie/business/personal-finance/ property-mortgages/urbanrural-divide-widens-as-capital-booms31167364.html [10 June 2015].

Williams, B. (Ed.) (2001). Shaping Dublin's future: Economic competitiveness and urban governance. Dublin: Faculty of the Built Environment, DIT.

Williams, B., Foley, W., Cudden, J., \& Shahumyan, H. (2012a). Dublin's role in the Irish and global economy synthesis report: Dublin Ireland's flagship. Dublin: School of Geography, Planning and Environmental Policy University College Dublin

Williams, B., Hughes, B., Redmond, D., \& Cudden, J. (2012b). Demographic trends in Dublin - Report for Dublin City Council. Dublin: School of Geography, Planning and Environmental Policy, University College Dublin, with Dublin Institute of Technology.

Williams, B., Hughes, B., \& Shiels, P. (2007). Urban sprawl and market fragmentation in the Greater Dublin Area. Dublin: Society of Chartered Surveyors.

Williams, B., \& Shiels, P. (2002). The expansion of Dublin and policy implication of dispersal. Journal of Irish Urban Studies, 1 (1), 1-21.

Williams, B., Walsh, C., \& Boyle, B. (2010). The development of the functional urban region of Dublin: Implications for regional development markets and planning. Dublin: School of Geography, Planning and Environmental Policy, University College Dublin.

Wintour, P. (2014, May 14). George Osborne offers devolution route to cities with elected mayor. Retrieved from http://www.theguardian.com/ politics/2015/may/14/george-osborne-invites-cities-to-follow-manchesterroute-to-devolution [10 July 2015].

World Bank. (2014). Urban development statistics. Retrieved from http://data.worldbank.org/topic/urban-development [10 July 2015]. 
World Bank. (2015). Urban development. Retrieved from http://www.world bank.org/en/topic/urbandevelopment [10 July 2015]. 